\title{
INTEGRATING THEMES OF CARE INTO ENGLISH CURRICULUM: TOWARD THE ENHANCEMENT OF STUDENTS' MORAL REASONING SKILL Sugiono
}

\author{
Universitas Nurul Jadid \\ ss.sugiono@gmail.com
}

\begin{abstract}
The purpose of the study is to explore possible strategies to 'insert' themes of care into Indonesia's English curriculum. It is stipulated that the English curriculum containing themes of care, ethics and morality can contribute to the advancement of students' engagement in learning and enable moral reasoning skill toward the generation of responsible members of society upholding values of tolerance and respect for difference of others. This is a library research, employing a qualitative content review of related literature to find strategies for integrating themes of care into English curriculum. It is found that integrating themes of care into curricular subjects, including English, is very possible to undertake, and provides students with higher order thinking skills in a functional manner. It is of great importance to students as they get benefits from being taught the ways to approach and eventually solve complex, real-life moral problems by applying particular skills drawn from the PAVE moral reasoning strategy. The English curriculum addressing such a long-term outcome for the application of the integration incorporates teaching students how to attain balanced competence, academically, socially and morally all at once.
\end{abstract}

Keywords: themes of care, ethics, English curriculum, PAVE, moral reasoning

\section{INTRODUCTION}

The research presented in this paper aims to find strategies to integrate themes of care into English curriculum in Indonesia. The paper argues that integrating themes of care into English curriculum potentially leads to students' engagement in learning and enables the generation of responsible members of society advocating tolerance and respect for diversity. This is of great importance, as since 1998 the locus of Indonesian education has shifted from a more centralised, bureaucratic, authoritarian model to a decentralised, democratic and value-based mode of operation. Suggested reforms for organisational systems have engendered efforts to introduce reform in curriculum and instruction. The results of the reform are the Competency-Based Curriculum $(K B K)$, 2006 Curriculum (KTSP) and 2013 Curriculum. The latest Indonesian Curriculum of 2013, which is currently being introduced to Indonesian schools, is expected to bring significant changes to students' performances. As opposed to the previous perspective of teaching that tends to be by rote and is teacher-centred, and emphasises memorising and task completion, this curriculum highlights the notion of teaching that encompasses integration of socio-cultural values (themes of care) and development of students' thinking (penalaran) and creativity (kreatifitas). 
The focusing questions that need to be answered are: Why is it important to teach students themes of care? How can such themes be built into English curriculum? What subject areas more suited for teaching themes of care?

\section{METHOD}

This paper uses a qualitative content review of related literature to find strategies for integrating themes of care into English curriculum.

\section{LITERATURE REVIEW}

\section{Themes of Care}

Themes of care constitute essential parts of ethics education. This is fundamental to anticipating the erosion of morality and social values amongst students such as drug and alcohol abuse, sexuality, teen pregnancy, cheating on homework, running a red light, and other behaviours disregarding the consequences of actions on others. In these circumstances, creating a moral community within schools is urgently required. "It may be unnecessary to argue that we should care more genuinely for our children and teach them to care" (Noddings, 2003, p. 59). In other words, students will care what you know if they know you care (Faber, 2015).

In Indonesia, teaching themes of care in school context drives less controversy, for, from the perspective of Indonesian society, schools have responsibility to teach their students ethics of care, and students ought to be able to explore ethical values in classroom settings. In this respect, education is inherently seen as an ethical enterprise, and "school life is a moral mosaic" (Preston, 2001, p. 214). "A value-free education is about as possible as a protein-free diet" (Shinn, 1980, p. 111). Hence, freeing education from themes of care and socio-moral values can be peculiar in Indonesia.

\section{Integrating Themes of Care into English Curriculum}

In contrast to Indonesia's notion of education, the educational perspective of some western countries does not promote the integration of themes of care into a curriculum (Noddings, 2003). The reason is that such themes are not objective or neutral, and hence educators involved in curriculum development may not easily agree upon them. They tend to view that it is the home, not the school, which has an ethical and moral obligation to children (Noddings, 2003). Schools have responsibility for just students' academic competence.

Nevertheless, from the educational perspective of Indonesia, such a view narrows down the essential points of education that need to incorporate transfer of knowledge and transfer of values at a time. The view constitutes 'emotional prejudice' rather than logic due to the growing trend of today's education, which fulfils mere needs of labour market and drives students to prefer just achieving academic competence for an employment opportunity. Consequently, few students may succeed both academically and socially, whereas success in both is better than success in either of them. In addition, human beings are basically social creatures. They are productive and dynamic and care about something. They are also rational, in the sense that they think and eventually make decisions. Accordingly, treating students in a way which is in line with the human basic nature is not wrong, and 


\section{VOL. 03 NO. 01 , JUNE 2021}

that schools responsible for both moral and academic competence is the right thing to do. Schools, at this stage, will act as a bridge between the miro-moral world of the home and the macro-impersonal ethical systems of society (Preston, 2001). It is thus of great importance for schools to think that teaching or advocating themes of care and integrating them into English curriculum can contribute to entailing affirmative changes in society.

Noddings (2003) suggests that there is much to be gained both academically and humanly by incorporating themes of care in curriculum. The inclusion can advance students' cultural literacy and connect students to their real life experiences. In addition, teaching themes of care potentially relates teachers to students person-to-person, in the sense that when teachers are discussing themes of care, they can become real persons to their students, and hence constructions of new knowledge are enabled. Themes of care presented in teaching imply a continuous search for character building. Integrating themes of care into teaching is not anti-intellectual. Rather, it potentially generates caring, capable, loving and lovable people that uphold moral values and demonstrate respect for human diversity.

Conceptually, although schools that hold the principal themes of care commonly have the same general goal of producing generations with both academic and moral competence, in practice they have different strategies for integrating themes of care into a curriculum to achieve the goal. Particular schools tend to set up core values, which lay the foundations for teaching, learning and care programs. In an American school, for instance, the core values serve as those of free democratic society, which include Patriotism, Loyalty, Faithfulness, Courage, the Ability to make the crucial moral distinctions between right and wrong, the Maturity to understand that all property and achievement in this world come first from the Beneficent and Loving God (Schafersman, 1998). It is believed that by making these values an explicit and central aspect of work, improved teaching and learning will naturally follow (Toomey, 2006, p. 5).

Nonetheless, drawing on Howe and Miramontes (1992), Cranston-Gingras et al. (1997) argue that the key to fostering effective ethical deliberation is not mere mastery of a given set of principles and precepts, but also practice in reasoning and collaborating about ethically problematic situations. According to Jewell et al. (n.d.), moral reasoning practice refers to the application of higher order critical thinking skills, combined with caring thinking skills, to solve problems of a moral nature by means of moral dilemmas. The consideration or discussion of moral dilemmas in teaching is believed to encourage students' moral development, actively involves the students in the process of decisionmaking, and demands their personal commitment to a choice (Jewell et al., n.d.).

Rusk et al. (2006) indicate that moral development exists due to an interaction between the child's cognitive structures and the structural features of the social environment. As Kohlberg's theory suggests, moral development is promoted by social experiences, which produce cognitive conflict and create opportunities for children to take the perspective of others. According to Kohlberg (1927), it is through social interaction, cognitive conflict, a positive moral atmosphere and democratic participation that students' moral thinking can be advanced educationally.

Kohlberg's theory does not directly relate to curriculum, yet it can become the philosophical basis for the development of it. His moral theory does help identify the age at which the youth are more likely to move from one developmental stage to another. According to Kohlberg, the youth are the 


\section{VOL. 03 NO. 01 , JUNE 2021}

focus of ethics education program, for most adults have already reached the upper stages of moral development. It is acknowledged that the higher the stage, the harder it is to influence individuals' ethics (see Kohlberg, 1927).

Further, teaching practice incorporating themes of care needs to give attention to the moral development of students. The major aim of teaching as such is to help students become better moraldecision makers and "think through moral/ethical questions so that they can, in their own way and on their own terms, come to be better people" (Millet \& College, 2002, p. 66). Inferring from the work of Dewey, Jewell et al. (n.d. p. 31) contend that subjects studied not simply for their technical worth, but also for the understanding of social conditions and contexts that they can engender in students, will "feed their moral interest and develop moral insight". Jewell et al. add that outcomes resulted from a moral development process can largely resist measurement, and even may not be measurable until the students graduate.

Drawing on Ozar, (2001) Millet and College (2002) recommend four categories of moral life that ethics educators can consider to work for growth in moral learners. These categories are:

- Awareness or sensitivity to what is morally/ethically at stake;

- Reasoning and other reflective skills leading to judgments about what should be done in a situation;

- Motivation/conviction - the person's conscious affirmation of a life lived according to values, principles and ideals;

- Implementation - the practical and emotional ability to carry out a course of action once it has been judged as something that should be done.

Hence, for the first instance, a course of study can be developed, which allows students to demonstrate the concrete outcomes of the first two categories. Even though the second two are more problematic, students are expected to be able to demonstrate, or at least, have thought of them.

The development of English curriculum highlighting themes of care needs to be focused on the process of moral decision-making and the provision of moral reasoning strategies for students in order to be able to assess moral questions and come to a considered judgment. Moral reasoning incorporates critical and caring thinking skills, and hence Bloom's taxonomy of cognitive processes (Knowledge, Comprehension, Application, Analysis, Synthesis, and Evaluation) and/or its new verb-based form (Remember, Comprehend, Apply, Analyse, Evaluate, and Create) are considered useful base for constructing questions of moral dilemmas (Jewell et al., n.d.). Nonetheless, despite its usefulness, they might be insufficient; there should be a supplement to the range of moral reasoning strategies so as to enable students to reflect on how they learn. In this respect, PAVE (Principles, Agreement, Virtues, End Consequences) moral reasoning strategy could be an ancillary to Bloom's taxonomy.

Following the notion of PAVE moral reasoning, an action is right if it follows certain fundamental moral principles such as 'don't treat other people as a means of an end', 'always tell the truth', 'be fair', and so forth. The best way to good treatment should lead to agreements about how to treat each other based on, for instance, community-made laws or regulations. An action is considered a virtue if it conforms to a set of attributes that are inherent in a particular community, which includes 


\section{VOL. 03 NO. 01 , JUNE 2021}

integrity, courage, compassion, and so on. An action is right if good consequences outweigh bad consequences, where 'good' could mean 'pleasure, welfare, satisfaction, and the like (Jewell et al., n.d; For the Greater Good: Curriculum Guide, 2004).

Jewell et al. (n.d.) believe that the PAVE moral reasoning strategy gives the moral reasoners (students) additional knowledge in terms of deliberating at greater depth and understanding, empowering them to make reasoned moral choices, understanding the basis of others' moral choices and developing skills of negotiating positive outcomes. Jewell et al. (n.d) also note that the moral reasoning strategy can encourage students to reflect on these four particular central questions:

- What could I do that is morally right?

- What should I do in this situation?

- What will I do?

- Why will I choose that is right?

To add a fifth and sixth:

- How do I know what is right?

- What do I mean by 'right'? (Mayo, 1986, p. 9).

These questions are reflective, and imply that integrating ethics, themes of care or morality into English curriculum by means of the PAVE moral reasoning strategy can potentially lead students to moral action rather than moral cognition, for, in that process, there is a disposition toward morality. "Without the disposition towards morality, the individual lacks the motivation for moral action" (see Jewell et al., n.d., p. 29). In addition, this strategy emphasises that themes of care, ethics and morality basically constitute practical subjects in that practical questions of how to be morally good are literally inescapable. Such a strategy also develops what they learn through their experiences, provides students with language activities that are 'beyond learning', and suggests that morality needs to be acquired and imparted. This means that students need to be more or less decent men and women as a result of some early processing, "by some forms of interaction between themselves and people who already have their moral standards; these people might be parents, preachers and/or teachers” (Mayo, 1986 p. 2).

In Indonesian educational reality, within the range of implementing the developed curriculum which contains themes of care, ethics, or morality, there has been a heated debate among scholars as to whether themes of care or ethics should become a separated subject, or be integrated into specific subjects, or even into all subjects including English.

Supporters of promoting themes of care or ethics to be a separated subject is based on the result of a research conducted in one of secondary schools in Bali, which demonstrates that there is a decrease in the percentage of violation among students towards the school regulations (Ethics Subject Using Monolithic Approach, 2005). However, students' obedience or disobedience to school regulations is merely a small part of ethics education in the sense that it might be too early to say that the program has succeeded in solving the problems of morality. In addition, students have a life outside their school, that is to say, the life in their home and wider community (Bempechat 2000, pp. 1-2). At this stage, how they live in their family and community should be the indicator of success or failure of the program. 


\section{VOL. 03 NO. 01 , JUNE 2021}

Further, integrating themes of care into Religion and Civics, in Indonesian context of education, is a must and inevitable in that for ages the two subjects have been recognised containing moral and ethical values. According to Shinn (1980, pp. 116-117), "values derive from a religious commitment; it is hard to imagine any serious religious commitment that does shape the values of its adherents". Meanwhile, Moran (2003, p. 27) notes that Civics echoes a fundamentally Aristotelian notion which concerns for the necessity of living in a good state in order to achieve a good life, as well as Rousseau's notions of virtuous citizens acting as legislators in a communal, participatory democracy.

However, Greenawalt (2005, p. 79) says, "We have no guarantee that teaching about religion will lead students to be more religious". By analogy, it could be stated that teaching civics does not necessarily drive students into being virtuous citizens as well. In the view of the fact of the moral or ethical problems, which has considerably increased so far, some scholars of Indonesian education recommend that teachers of Religion and Civics should alter their methods and techniques of teaching themes of care to the students (National Department of Education, 2001).

Nonetheless, the recommendation implies a particular perspective that the problems of morality become the responsibility of teachers of the two subjects, Religion and Civics. Whereas, Mayo (1986, p. 2) says, “... and by teachers I mean those who teach other things; the [English] teacher, for instance, teaches [English], but he may set a moral example too in truthfulness and integrity". Thus, themes of care, ethics, and morality should be the responsibility of all (English) teachers and integrated into curriculum subjects, including English.

Integrating themes of care into English is not an easy task, however. The reason is that for several decades English has been viewed as not having moral and ethical quality since it limits itself to the description of grammatical structure and translation, and merely puts emphasis on cognitive and psychomotoric aspects and resists affective contexts (Chain 1970, p. 1 as cited in Pritchard \& Buckland).

Therefore, specific claims have been made to enable all subjects, including English, to be legitimate vehicles for moral teaching. King and Reiss (1993, p. 5 as cited in Halstead \& Taylor) recommend that "all national curriculum subjects - including language and science - should have a contribution to make to developing the values of cultural diversity". In particular, it is stated that language and science have the potential to develop a framework of social values and personal attitudes towards community, culture, and environment (Poole 1995, as cited in Halstead \& Taylor; Pritchard \& Buckland 1986). Siraj-Blatchford (1994 as cited in Halstead \& Taylor) notes the possibility of language and science to be a means of developing multicultural and anti-racist values. In other words, in such contexts, teaching strategies will go beyond students' cognitive domain and provide them with space for the development of their affective domain.

THE SAMPLE OF ENGLISH CURRICULUM CONTAINING THEMES OF CARE The sample below covers School-Based Curriculum of English subject matter. Unlike Civics and Religion, the subject matter is not explicitly or directly related to themes of care, ethics, or morality.

Subject $\quad:$ English 


\section{VOL. 03 NO. 01 , JUNE 2021}

Class

$$
\text { : X (Ten) }
$$

Semester

$$
\text { : I }
$$

\begin{tabular}{|c|c|}
\hline Basic Competence & $\begin{array}{l}\text { Describing the characteristics of replication, and the roles of virus in } \\
\text { life. }\end{array}$ \\
\hline Material Details & $\begin{array}{l}\text { Virus: } \\
\text { - Characteristics of virus } \\
\text { - Replication of virus } \\
\text { - Roles of virus in life }\end{array}$ \\
\hline Learning Activities & $\begin{array}{l}\text { - Identifying the characteristics of virus } \\
\text { - Concluding the replication of virus } \\
\text { - Finding information on the advantages and disadvantages of virus } \\
\text { - Identifying how to avoid virus }\end{array}$ \\
\hline Indicators & $\begin{array}{l}\text { - Differentiating structures of virus from those of other living things } \\
\text { - Explaining the replication of virus } \\
\text { - Explaining the advantages \& disadvantages of virus } \\
\text { - Communicating how to avoid virus }\end{array}$ \\
\hline Evaluation & $\begin{array}{l}\text { - Individual work } \\
\text { - Group work } \\
\text { - Performance } \\
\text { - Observation of attitudes and behaviours } \\
\text { - Comprehension test }\end{array}$ \\
\hline Time Allotment & $4 \times 45$ minutes \\
\hline Sources/Instruments & $\begin{array}{l}\text { Textbooks, students' worksheet, drawings/charts/pictures of various } \\
\text { living things, newspapers, and magazines }\end{array}$ \\
\hline Moral Dilemma & Should the authority quarantine people infected by HIV/AIDS Virus? \\
\hline
\end{tabular}

Standard Competence $\quad$ : Understanding texts about principles of grouping living things.

In terms of the implementation, both can use these four learning stages: Building Knowledge of Field, Modelling, Joint Construction, and Independent Construction. For the first two stages, teachers provide students with the context of moral dilemmas presented, and with the concept of PAVE moral reasoning strategies. In Joint Construction, students work in groups to learn considering different perspectives of moral judgment from their peers, which may promote an understanding of many dimensions of an ethical decision making. During this stage, teachers' intervention is still required. Then, Independent Construction deals with assigning every single student to apply the moral reasoning strategy independently with no more teachers' intervention.

In addition, what is of the greatest importance is the presentation of guiding questions about the moral dilemmas, which reflects the PAVE moral perspective. Those questions can be in between the 
first two learning stages (Building Knowledge of Field and Modelling) and the last two (Joint and Independent Constructions). The possible questions may be as follows:

\section{Principles:}

- Is quarantining people, even though they contract an infectious disease, is ethically acceptable?

- It is stated that freedom is a fundamental principle. Is the principle applicable for all people with no exception?

\section{Agreements:}

- Is there a particular law which regulates the treatment of people who suffer from AIDS?

- Do you agree with some people saying that those who are infected by HIV were previously immoral persons?

Virtues:

- Why are those people to be quarantined?

- Are there any other ways beside the quarantine?

\section{Consequences:}

- Who is affected by them to be quarantined?

- Is it better to sacrifice principles or agreements in order to gain good consequences?

\section{CONCLUSION AND RECOMMENDATION}

Integration of themes of care into all curriculum subjects is not only very possible to do, but also gives students higher order thinking skills in a functional manner. It is of value to all students since they can get benefits greatly from being taught how to approach and eventually solve complex, real-life moral problems by applying particular skills with skills learned from other areas of curriculum. Curricula addressing such a long-term outcome for the application of the integration might involve teaching students how to achieve balanced competence, academically and morally all at once.

Since the kind of teaching and learning process requires teachers' creativity, the Ministry of National Education should hold ethics educational trainings for all teachers in order that teachers could have sufficient knowledge, competence, and skills in the development, implementation, and evaluation of the themes-of-care-added curriculum. 


\section{VOL. 03 NO. 01 , JUNE 2021}

\section{REFERENCES}

Bempechat, J 2000, Getting our kids back on track: Educating children for the future, JosseyBass Inc., San Fransisco.

Cranston-Gingras, A, Raines, S, Thompson, TD, \& Beach, D 1997, 'Teaching Ethics Through the Case Method' in (Eds) J.L. Paul, N.H. Berger, P.G. Osnes, Y.G. Martinez, \& W.C. Morse, Ethics and Decision Making in Local Schools: Inclusion, Policy, and Reform, Paul H. Brookes Publishing, Maryland.

For the Greater Good: Curriculum Guide 2004, Northwest Association for Biomedical Research, Draff 2004. <www.nwabr.org>

Greeanawalt, K 2005, Does God belong in public schools?, Princeton University Press, New Jersey.

Halstead, JM \& Taylor, MJ 2000, 'Learning and teaching about values: A review of recent research', Cambridge Journal of Education, Vol. 30, no. 2, pp. 1-34.

Jewell, P, Webster, P, Henderson, L, Dodd, J, Paterson, S, \& McLaughlin, J n.d., 'Care, Think, and Choose: A Curriculum Based Approach to Teaching Ethics', handout prepared for EDES 9639 (2007) Ethics in Education, Flinders University, Adelaide.

Kohlberg, L 1927, Psychology of Moral Development: the Nature and Validity of Moral Stages, Harper \& Row, San Francisco.

Mayo, B 1986, The Philosophy of Right and Wrong: An Introduction to Ethical Theory, Routledge \& Kegan Paul, London.

Millet, S 2002, 'Teaching Ethics (And Metaphysics) in an Age of Rapid Technological Convergence', Teaching Ethics, Spring, Vol. 2, No. 2, pp. 53-69.

$<$ http://www.rit.edu/ 692awww/seac/Vol2.2.html>

Moran, ET 2003, 'Civic Responsibility and Teaching Macroethics', Teaching Ethics, Vol. 2, No. 2, pp. 27-54. <http://www.rit.edu/ 692awww/seac/Vol2.2.html>

Noodings, N 2003, 'Teaching Themes of Care' in (Eds) A.C. Ornstein, L.S. BeharHorenstein, \& E.F. Pajak, Contemporary Issues in Curriculum, Pearson Education, Boston.

Pelajaran Budi Pekerti dengan Pendekatan Monolitik (Ethics Subject Using Monolithic Approach), 2005, Republika, December 24. <republika.co.id>

Pendekatan-pendekatan Pendidikan Nilai dan Implementasi Pendidikan Budi Pekerti (Approaches to Values Education and Implementation of Ethics Education), Portal Informasi Pendidikan di Indonesia, 2001, Departemen Pendidikan Nasional. <www.depdiknas.go.id>

Preston, N 1996, Understanding Ethics, Federation Press, NSW.

Print, M 1987, Curriculum Development and Design, Allen \& Unwin, Australia.

Pritchard, AJ \& Buckland, DJ 1986, 'Leisure, Values, and Biology Teaching', Science and Technology Education, Document series no. 22, pp. 1-16, Division of Science Technical and Environmental Education, UNESCO.

Rusk, CP, Brubaker, KM, Balschweid, MA, \& Pajor, EA 2006, 'Evaluation of a Livestock Ethics Curriculum for High School Youth', Journal of Agricultural Education, Vol. 47, 


\section{VOL. 03 NO. 01 , JUNE 2021}

No. 3, pp 105-116.

Schafersman, SD 1998, 'Teaching Morals and Values in the Public schools: A Humanist Perspective’, Steven D. Schafersman. <schafesd@humanism.net>

Shinn, RL 1980, 'Education in Values: Acculturation and Exploration' in (Eds) D. Sloan, Education and Values, Teachers College Press, New York.

Toomey, R 2006, 'Values as the Centrepiece of the School's Work: A discussion Paper on Learning from VEGPSP Stage 1', paper prepared for the First Briefing Session of the Values Education Good Practice Schools Project - Stage 2, n.d. October. 